\title{
EFFECT OF SEX RATIO IN UTERO ON DEGREE OF TRANSFORMATION AND CHIMAERISM IN NEONATAL BOVINE FREEMARTINS*
}

\author{
D. B. LASTER, $¥$ E. J. TURMAN, $\uparrow$ B. H. JOHNSON, $\uparrow \$$ \\ D. F. STEPHENST AND R. E. RENBARGER \\ $\dagger$ Department of Animal Sciences and Industry, Oklahoma State University, Stillwater, and \\ IU.S. Department of Agriculture, El Reno, Oklahoma, U.S.A.
}

(Received 21st April 1970, revised 28th Fuly 1970)

\begin{abstract}
Summary. Seventeen neonatal bovine freemartins from eight twin, six triplet, two quadruplet, and one quintuplet, births were studied to determine whether the ratio of males to females in utero modified the severity of transformation of the reproductive system, type and extent of gonadal tissue and the proportion of polymorphonuclear neutrophil leucocytes containing sex nodules.

The degree of masculinization of the reproductive system ranged from those having no differentiation of the Müllerian ducts anterior to the vagina to those with a rudimentary uterus and two gonads. Testicular tissue was found in the gonads of five of the six freemartin reproductive tracts in which gonads were observed.

As the male: female sex ratio at birth increased, the proportion of sex nodules decreased and the degree of transformation of the reproductive system increased.
\end{abstract}

\section{INTRODUGTION}

In cattle, simultaneous development of male and female foetuses has been invoked to explain the modifications which may occur in the development of the reproductive system of the female twin, presumably due to androgens produced by the male co-twin (Lillie, 1917). Recent cytogenetic and steroid studies have indicated that this classical explanation does not adequately explain the freemartin syndrome (Ryan, Benirschke \& Smith, 1961; Fechheimer, Herschler \& Gilmore, 1963; Jost, 1955, 1967; Herschler \& Fechheimer, 1967; Short, Hamerton, Grieves \& Pollard, 1968).

Fechheimer et al. (1963) and Herschler \& Fechheimer (1967) suggested that the primary factor modifying gonadal development in freemartins is the presence of Y-chromosome-bearing cells in the genetic female at the time of gonadal differentiation.

Jost $(1955,1967)$ suggested that the foetal gonad of the genetic female may

* Approved as Journal Manuscript No. 1999 of the Oklahoma Agricultural Experiment Station.

\$ Present address: Department of Animal Science, Iowa State University, Ames, Iowa, U.S.A.

S Present address: Department of Physiology and Pharmacology, Oklahoma State University, Stillwater, Oklahoma, U.S.A. 
produce both a testosterone-like androgen that stimulates the Wolffian ducts and another substance, not necessarily steroidal, that suppresses and causes regression of the Müllerian ducts.

Several reports have indicated that the sex nodule seen in female polymorphonuclear neutrophil leucocytes is morphologically equivalent to the sex chromatin mass which may be observed in tissue cells and that there is a constant relationship between the number of sex chromosomes and sex chromatin in normal or mosaic individuals (Davidson \& Flute, 1962; Miller, 1962; MacLean, 1962; Murthy \& Haam, 1962). This suggests that the proportion of sex nodules in the polymorphonuclear leucocytes is an indication of the degree of chimaerism in the bovine freemartin.

Although there is a vast amount of information on the bovine freemartin in the literature, no studies of group comparisons of neonatal freemartins from twin, triplet, quadruplet and quintuplet births have been reported.

The purpose of this study was twofold: to provide further information on the effect of sex ratio in utero on the degree of transformation of the reproductive systems and to compare the relationships between the sex ratio at birth, the proportion of sex nodules in the polymorphonuclear leucocytes, the presence of testicular tissue in the gonads and the degree of transformation of the reproductive tract of seventeen neonatal bovine freemartins.

\section{MATERIALS AND METHODS}

The freemartins were produced by using a sequence of two pregnant mare's serum gonadotrophin (PMSG) injections to induce multiple births in beef cattle (Turman, Renbarger \& Stephens, 1968). The types of multiple births with the numbers of calves from which data were obtained are shown in Table 1. In

TABLE 1

TYPE OF MULTIPLE BIRTHS AND NUMBERS OF ANIMALS FROM WHICH DATA WERE COLLEGTED

\begin{tabular}{cc|c|cc}
\hline \multicolumn{2}{c|}{$\begin{array}{c}\text { Type of multiple birth } \\
\text { Male }\end{array} \quad$} & Female & $\begin{array}{c}\text { No. of } \\
\text { multiple } \\
\text { births }\end{array}$ & \multicolumn{2}{|c}{ Data obtained from } \\
Males & Females \\
\hline 1 & 1 & 9 & 5 & 8 \\
2 & 2 & 1 & 1 & 1 \\
1 & 2 & 6 & 3 & 5 \\
1 & 3 & 1 & 0 & 1 \\
2 & 1 & 1 & 1 & 1 \\
4 & 1 & 1 & 1 & 1 \\
0 & 2 & 1 & 0 & 2 \\
2 & 0 & 2 & 4 & 0 \\
\hline
\end{tabular}

addition, data were collected from eighteen single-birth female and fourteen single-birth male calves of similar ages and breeding.

Vaginal smears were taken from all females to determine the genetic sex according to the method of Greenblatt \& Manautou (1957). Sex nodule counts were determined from smears prepared from peripheral blood collected from all 
male and female animals before slaughter (Greenblatt \& Manautou, 1957). At least 250 polymorphonuclear leucocyte nuclei were counted to determine the percentage containing a sex nodule. Both 'drumsticks' (Pl. 1, Fig. 7) and 'sessile bodies' (Pl. 1, Fig. 8) were included in the sex nodule counts (Sohval, 1963).

Mammary gland development was rated subjectively at 10 months of age by measuring teat length and by palpating the gland. Ratings ranged from 1 to 5; 1 for normal and 5 for those most inhibited.

Reproductive tracts were recovered from all females at 12 months of age, examined for gross abnormalities and assigned an overall transformation rating from 1 (normal) to 5 (very extreme). The subjective rating was based primarily on the presence of feminine structures and their relative degree of transformation. All gonads and samples of tissue from other reproductive organs were fixed in Bouin's fluid. Following routine processing and paraffin-wax embedding procedures, the tissue was sectioned and stained with haematoxylin and eosin for microscopic examination.

\section{RESULTS}

All females from heterosexual births were freemartins with female external genitalia. All freemartins had an enlarged and/or segmented clitoris; however, no structure resembling a vestigial penis was observed. The mean vaginal length in the dissected freemartin reproductive tracts was $11.2 \pm 1.9 \mathrm{~cm}$ terminating at a point comparable to the urethral fold in the normal female. The mean vaginal length from the clitoris to the urethral fold in the normal female was $11 \cdot 9 \pm 1.0 \mathrm{~cm}$. Total vaginal length from the clitoris to the cervix in the normal female was $37 \cdot 0 \pm 4 \cdot 1 \mathrm{~cm}$.

The degree of transformation and inhibition of the internal reproductive structures in all freemartins was extreme to the extent that none approached normal, but relative differences within and among those from the different sex ratios at birth were noted (Pl. 1, Figs. 1 to 6 ). The degree of masculinization of the tracts ranged from those having undifferentiated ducts with no development of feminine structures anterior to the vagina to those with a rudimentary uterus and two gonads. Müllerian ducts anterior to the vagina failed to differentiate in eight freemartins with each of the reproductive tracts having one or two juvenile seminal vesicles. No structures resembling a cervix were found in any of the freemartin reproductive tracts and only one had a rudimentary oviduct.

Freemartins from births with a higher female: male ratio had a higher proportion of female and a lower proportion of male structures than those from births with an equal or greater number of males than females (Table 2). Gonads from five of the six freemartins contained seminiferous tubules and other tubular testicular tissue. The freemartin with the rudimentary oviduct was from a birth with one male and two females and was the only freemartin having gonads with no testicular tissue.

All freemartins were genetic females. Sex chromatin was found in $60 \%$ of the vaginal epithelial nuclei counted, with values ranging from 50 to $70 \%$ in both the normal females and the freemartins. 
The mean numbers of sex nodules and range/100 polymorphonuclear leucocyte nuclei for the normal females, freemartins and freemartin co-birth males, respectively, were $5 \cdot 0 \pm 1 \cdot 4,4$ to $7 ; 1 \cdot 75 \pm 2,0$ to $4 ; 0 \cdot 64 \pm 0.4,0$ to 2 . No sex nodules were found in the polymorphonuclear leucocytes of the normal males. The normal females had a significantly higher $(P<0.01)$ proportion of sex nodules than the freemartins and the freemartin co-birth males.

TABLE 2

EFFECT OF SEX RATIO in utero ON PRESENCE OF MALE AND FEMALE REPRODUCTIVE ORGANS

\begin{tabular}{c|c|ccccc}
\hline \multirow{2}{*}{$\begin{array}{c}\text { Birth sex } \\
\text { ratio }\end{array}$} & $\begin{array}{c}\text { No. } \\
\text { animals }\end{array}$ & $\begin{array}{c}\text { No. freemartins with reproductive organs present } \\
\text { Uterus or } \\
\text { gonads }\end{array}$ & $\begin{array}{c}\text { Uterus and } \\
\text { gonads }\end{array}$ & $\begin{array}{c}\text { Uterus and } \\
\text { no gonads }\end{array}$ & $\begin{array}{c}\text { Gonads and } \\
\text { no uterus }\end{array}$ & $\begin{array}{c}\text { Seminal } \\
\text { vesicles }\end{array}$ \\
\hline $\begin{array}{c}\text { Males < females } \\
\text { Males = females }\end{array}$ & 6 & 5 & 3 & 1 & 1 & 5 \\
Males > females & 2 & 4 & 1 & 2 & 1 & 8 \\
\hline
\end{tabular}

Sex ratio at birth appeared to modify the percentage of sex nodules and degree of masculinization of the reproductive systems (Table 3). As the male: female sex ratio increased, the proportion of sex nodules decreased and the degree of transformation of the reproductive system increased. No relationships were noted between type of tissue in the gonads and other characteristics studied, except that the one freemartin with a rudimentary oviduct and no testicular tissue in the gonads had three sex nodules/100 polymorphonuclear leucocyte nuclei compared to two for others from the same male:female birth ratio. The six freemartins with gonads had an average of $2.5 \pm 1.8$ sex nodules/ 100 polymorphonuclear leucocytes compared to the overall mean of $1 \cdot 7 \pm 1 \cdot 2$.

\section{EXPLANATION OF PLATE 1}

Figs. 1 to 4 are representative reproductive tracts of freemartins from different sex ratios at birth. Figs. 5 and 6 show typical Müllerian ducts, rudimentary gonads and a rudimentary uterine structure from freemartin reproductive tracts. Figs. 7 and 8 are examples of two types of sex nodules included in the study.

FIG. 1. A freemartin reproductive tract from a birth with one male and three females. This tract contained a shortened vagina, two seminal vesicles and a uterine structure with two blind horns. The right arrow indicates a gonad and the left arrow a cyst structure with no gonadal tissue.

Fig. 2. A freemartin reproductive tract from a birth with one male and one female. The only differentiation of the Müllerian ducts anterior to the vagina is one ovo-testis. The arrows indicate seminal vesicles.

Fic. 3. A freemartin reproductive tract from a birth with two males and one female. There are no female structures anterior to the vagina; however, both ducts end with a slight increase in size.

Frg. 4. A freemartin reproductive tract from a birth with four males and one female. Total inhibition of the Müllerian ducts anterior to the rudimentary vagina.

Fig. 5. The arrows indicate gonads at the end of the Müllerian ducts.

Fig. 6. A typical uterine structure and two gonads. The arrow indicates an ovarian plexus.

Frg. 7. A 'drumstick' of a polymorphonuclear neutrophil leucocyte nucleus.

Fig. 8. A 'sessile body' in a bilobar neutrophil leucocyte nucleus. 
PLATE 1
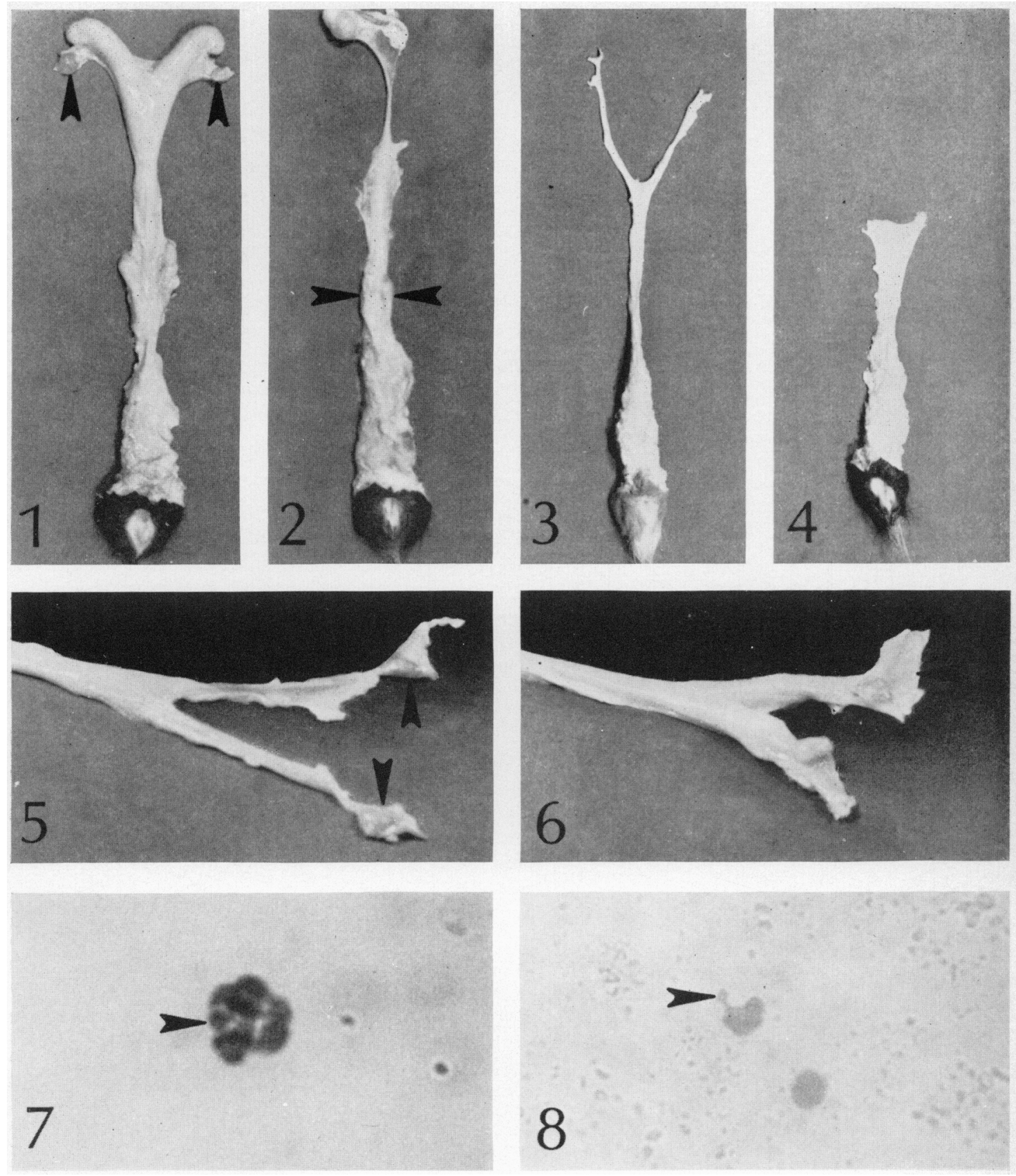

(Facing p. 364) 
The degree of mammary gland development in the freemartins was significantly more inhibited $(P<0.01)$ than in the normal females; a mean score of $2 \cdot 7 \pm 0.6$ for the freemartins compared to $1.0 \pm 0$ for the normal females. No differences in mammary development among the different sex ratios at birth were noted.

TABLE 3

BIRTH SEX RATIO, PROPORTION OF SEX NODULES, DEGREE OF TRANSFORMATION OF THE REPRODUCTIVE TRAGT AND TESTIGULAR TISSUE IN THE GONADS OF FREEMARTINS

\begin{tabular}{c|c|c|c|c|c}
\hline $\begin{array}{c}\text { Birth sex } \\
\text { ratio }\end{array}$ & $\begin{array}{c}\text { No. } \\
\text { freemartins }\end{array}$ & $\begin{array}{c}\text { Mean no. } \\
\text { sex nodules }\end{array}$ & $\begin{array}{c}\text { Mean scores } \\
\text { of rep. tracts }\end{array}$ & $\begin{array}{c}\text { No. animals } \\
\text { with gonads }\end{array}$ & $\begin{array}{c}\text { No. gonads } \\
\text { with test. tissue }\end{array}$ \\
\hline Males < females & 6 & $2 \cdot 0 \pm 1 \cdot 2$ & $3 \cdot 5 \pm 1 \cdot 0$ & 4 & 3 \\
Males = females & 9 & $1 \cdot 6 \pm 1 \cdot 4$ & $4 \cdot 3 \pm 0.6$ & 2 & 2 \\
Males > females & 2 & $1 \cdot 2 \pm 0.5$ & $5 \cdot 0 \pm 0.0$ & 0 & 0 \\
\hline
\end{tabular}

\section{DISCUSSION}

The degree of transformation of the reproductive tracts from the freemartins described in this report was more extreme than for similar individuals described in the literature; especially those from births with a higher female:male ratio (Bissonnette, 1933; Rajakoski \& Hafez, 1963).

The length of the vagina from the clitoris to the urethral fold which was comparable in both freemartins and normal females offers good evidence that the vagina had completed, or neared completion of its differentiation to this point before any inhibitory influences from the co-birth male could manifest themselves regardless of the sex ratio in utero.

The proportion of freemartins in which gonads were absent was less than that generally reported in the literature (Rajakoski \& Hafez, 1963; Herschler \& Fechheimer, 1967). On the other hand, Sweet, Matthews \& Graves (1940) reported on fifteen freemartins studied up to 18 months of age and found a high percentage with no gonads. A large proportion of the freemartins with gonads were from births with a higher female : male ratio and these tracts were less masculinized and included a lower proportion with seminal vesicles. Therefore, it would appear that the differentiation of the internal organs in some instances was totally inhibited and the gonads did not develop. Sweet $e t$ al. (1940) found that the size of the rudimentary penis decreased and that of the mammary gland increased in some freemartins while the reverse occurred in others from birth to 18 months of age. This suggests that the gonadotrophin levels may vary widely among neonatal freemartins and might also suggest that regression of the gonads after parturition was partly responsible for the total absence of gonads in eleven of the freemartins.

The presence of juvenile seminal vesicles in fifteen of the seventeen reproductive tracts, the enlarged clitoris, decreased mammary gland development and total suppression of the differentiation of the Müllerian ducts anterior to the 
urethral fold of the vagina might support the suggestions of Jost $(1955,1967)$ that the foetal testis may produce testosterone-like substances that stimulate the Wolffian ducts and another substance that causes regression of the Müllerian ducts. However, this would not account for the absence of gonads in eleven of the freemartin tracts unless they regressed following birth.

These data would not support the foetal hormone threshold level proposed by Bissonnette (1933) that freemartins from births with a higher male:female ratio are not masculinized to a greater degree than those from twin births.

The presence of sex nodules in the leucocytes of the freemartin co-birth males and the lower number of sex nodules in the freemartins than in the normal females is evidence that an exchange of primordial blood-forming cells occurred between the embryos of different sex in utero. The presence of a higher proportion of sex nodules, indicating more $\mathrm{X}$ - and fewer $\mathrm{Y}$-chromosomes, in the less masculinized freemartins having gonads might offer evidence to support the theory that the proportion of Y-chromosomes in the female is an aetiological agent in the freemartin syndrome. In addition, the absence of testicular tissue in the gonads and the greater proportion of sex nodules in the freemartin that had a rudimentary oviduct might also provide support for this theory.

\section{AGKNOWLEDGMENTS}

The authors express their appreciation to Dr Claude Desjardins for his helpful suggestions during the preparation of the manuscript.

\section{REFERENCES}

BissonnetTe, T. H. (1933) Notes on multiple pregnancies in cattle with special reference to three cases of prenatal triplets and the freemartins involved. Am. F. Anat. 42, 29.

Davidson, W. M. \& Flute, P. T. (1962) Sex dimorphism in polymorphonuclear neutrophil leucocytes. Acta cytol. 6, 13.

Feghheimer, N. S., Herschler, M. S. \& Gilmore, L. O. (1963) Sex chromosome mosaicism in unlike sexed cattle twins. In: Genetics Today, p. 265. Ed. S. J. Geerts. Pergamon Press, London.

Greenblatt, R. A. \& Manautou, J. M. (1957) A simplified staining technique for the study of chromosomal sex in oral mucosal and peripheral blood smears. Am. F. Obstet. Gynec. 74, 629.

Herschler, M. S. \& Fechreimer, N. S. (1967) The role of sex chromosome chimerism in altering sexual development of mammals. Cytogenetics, 6, 204.

Jost, A. (1955) Modalities in the action of gonadal and gonad stimulating hormones in the foetus. Mem. Soc. Endocr. 4, 237.

Jost, A. (1967) Steroids and sex differentiation of the mammalian foetus. Proc. 2nd Int. Congr. Hormonal Steroids, Milan, 1966. Excerpta med. int. Congr. Ser. 132, 74. Amsterdam.

Lillie, F. R. (1917) The free-martin; a study of the action of sex hormones in the foetal life of cattle. 7. exp. Zool. 23, 371.

MacLean, N. (1962) The drumsticks of polymorphonuclear leucocytes in sex-chromosome abnormalities. Lancet, $\mathbf{i}, 1154$.

Miller, O. J. (1962) Sex determination: the sex chromosomes and the sex chromatin pattern. Fert. Steril. 13, 93.

Murthy, M. S. N. \& HaAm, E. von (1962) The occurrence of the sex chromatin in normal and pathological white blood cells. Acta cytol. 6, 127.

RAJAKoski, E. \& Hafez, E. S. E. (1963) Derivatives of cortical cords in adult freemartin gonads of bovine quintuplets. Anat. Rec. 147, 457.

Ryan, K. J., BentrschKe, K. \& SMith, O. W. (1961) Conversion of androstenedione-4- $\mathrm{C}^{14}$ to estrone by the marmoset placenta. Endocrinology, 69, 613.

Short, R. V., Hamerton, J. L., Grieves, S. A. \& Pollard, G. E. (1968) An intersex goat with a bilaterally asymmetrical reproductive tract. . Reprod. Fert. 16, 283. 
Sorval, A. R. (1963) Chromosomes and sex chromatin in normal and anomalous sexual development. Physiol. Rev. 43, 306.

Sweet, W. W., Matthews, C. A. \& Graves, R. R. (1940) Early recognition of the freemartin condition in heifers twin-born with bulls. F. agric. Res. 61, 587.

Turman, E. J., Renbarger, R. E. \& Stephens, D. F. (1968) Multiple births of beef cows treated with PMs. F. Anim. Sci. 27, 1198. 